ARTIKEL PENELITIAN

\title{
Uji Validitas Bender-Gestalt Test dengan Menggunakan Nijmeegse Schoolbekwaamheids Test (NST) sebagai Kriteria untuk Mendeteksi Kesiapan Anak Masuk Sekolah Dasar
}

\author{
GHOZALI RUSYID AFFANDI* \& LELY IKA MARIYATI \\ Fakultas Psikologi Universitas Muhammadiyah Sidoarjo
}

\begin{abstract}
ABSTRAK
Artikel ini disusun dengan harapan semakin banyaknya alternatif tes kesiapan masuk sekolah dasar yang dapat dilakukan oleh praktisi psikologi. Penelitian ini bertujuan untuk menguji vailidtas tes Bender-Gestalt (BG) dengan menggunakan Nijmeegse Schoolbekwaamheids Test (NST) sebagai kriteria. Fokus dalam kajian ini adalah satu variabel, yaitu; kesiapan sekolah dasar. Penelitian bersifat kuantitatif deskriptif dan korelasional, dengan partisipan dalam kajian ini terdiri 397 anak dari tiga sekolah yang tersebar di Sidoarjo, Bangkalan dan Probolinggo. Hasil skor tes BG dengan skor NST (sebagai kriteria) menunjukkan adanya korelasi positif $(r=.337$, nilai $\mathrm{p}<0.01)$. Hal ini menunjukkan bahwa tes BG memiliki validitas konkuren yang baik ketika dibandingkan dengan alat yang menjadi kriterianya yaitu Nijmeegse Schoolbekwaamheids Test (NST).
\end{abstract}

Kata kunci: kesiapan masuk sekolah dasar, Nijmeegse Schoolbekwaamheids Test (NST), tes BenderGestalt (BG)

\begin{abstract}
This article was arranged with the expectation of the growing number of school readiness alternative tests that can be carried out by psychological practitioners. Our research aimed to test the validity of Bender-Gestalt Test (BG-Test) by using Nijmeegse Schoolbekwaamheids Test (NST) as a criterion. The focus of this study was school readiness. The study was a descriptive quantitative and correlational study involving 397 students from three schools in Sidoarjo, Bangkalan, and Probolinggo. The results of the scores BG test with a score of NST (as the criteria) showed the existence of the positive correlation $(\mathrm{r}=.337, \mathrm{p}$-value $<0.01)$. This indicates that $\mathrm{BG}$ test was concurrently validated when compared to Nijmeegse Schoolbekwaamheids Test (NST) as its criteria.
\end{abstract}

Keywords: primary school readiness, Nijmeegse Schoolbekwaamheids Test (NST), Bender-Gestalt test (BG) 
INSAN Jurnal Psikologi dan Kesehatan Mental, 2017, Vol. 2(2), 84-95, doi: 10.20473/jpkm.v2i22017.84-95

Dikirimkan: 22 November 2017 Diterima: 13 Juli 2018 Diterbitkan: 18 Juli 2018

Editor: Ilham Nur Alfian

*Alamat korespondensi: Jl. Raya Gelam 250 Candi Sidoarjo Jawa Timur. Pos-el: ghozali@umsida.ac.id

Naskah ini merupakan naskah dengan akses terbuka dibawah ketentuan the Creative Common Attribution License (http://creativecommons.org/licenses/by/4.0), sehingga penggunaan, distribusi, reproduksi dalam media apapun atas artikel ini tidak dibatasi, selama sumber aslinya disitir dengan baik.

\section{PE N D A H U L U A N}

Saat ini salah satu indikator kemajuan suatu negara dapat dilihat dengan mengukur kualitas lembaga pendidikan yang tumbuh di negara tersebut baik dari segi pengajaran, fasilitas maupun prestasi pendidik dan anak didik. Kualitas pendidikan tersebut tentunya tidak datang begitu saja, hal itu dapat terwujud karena adanya upaya sekolah dalam mempersiapkan anak didiknya, seperti dengan melakukan pengukuran terhadap kesiapan anak masuk sekolah dasar.

Kesiapan anak masuk sekolah dasar adalah keterampilan khusus yang telah dimiliki anak untuk melaksanakan tugas-tugasnya secara akademik di awal pendidikan di sekolah dasar sebagai modal untuk belajar baca, tulis dan hitung (calistung). Faktor-faktor yang mempengaruhi kesiapan anak masuk sekolah dasar menurut Kustinah, dkk. (2007) adalah kesehatan fisik, usia, tingkat kecerdasan, stimulasi yang tepat dan motivasi. Sementara Papalia, dkk (2008) menambahkan bahwa ada 3 faktor yang mempengaruhi kesiapan/perkembangan manusia, yaitu keturunan, lingkungan, serta kematangan tubuh dan bagian otak. Kesiapan anak masuk sekolah dasar terdiri dari 2 bentuk kesiapan aspek utama, yaitu kesiapan aspek fisik dan psikologis. Sementara itu untuk kesiapan aspek psikologis terdiri atas kesiapan aspek emosi, sosial, dan mental (Hurlock, 1974). Pada anak-anak yang memiliki kesiapan masuk sekolah dasar akan memperoleh keuntungan dan kemajuan dalam perkembangan belajarnya, sedangkan bagi anak yang belum siap akan rentan mengalami frustasi ketika bersekolah (Sulistyaningsih, 2005). Hal tersebut tentunya dapat diantisipasi sejak awal apabila anak dapat diidentifikasi kesiapannya untuk masuk sekolah dasar, sehingga dapat diambil langkah-langkah intervensi.

Pada dasarnya sebuah tes psikologi adalah alat ukur yang objektif dan dilakukan atas sampel perilaku. Nilai diagnostik atau prediktif tes psikologi tergantung pada sejauh mana tes menjadi indikator dari bidang perilaku yang relatif luas dan signifikan. Tujuan tes psikologi adalah klasifikasi, deskripsi, interpretasi, serta prediksi. Khusus dalam bidang pendidikan, tes psikologi menyangkut inteligensi, minat dan bakat, kesulitan belajar, kesiapan sekolah, dan sebagainya. Alat tes psikologi tidak hanya digunakan untuk klasifikasi gangguan-gangguan psikis atau diagnosis, tetapi lebih tertuju pada pendeskripsian atau pemahaman yang lebih mendalam dari partisipan (Anastasi \& Urbina, 2006).

Berbagai jenis alat tes psikologi tersusun berdasarkan banyaknya tes, cara menyelesaikan tes, cara menilai tes, fungsi psikis yang dijadikan testing, tipe tes, materi tes, bentuk tes, pencipta tes, serta aspek yang diukur (Anastasi \& Urbina, 2006). Kaitannya dengan tes psikologi di dunia pendidikan khususnya dalam tujuan pengukuran kesiapan anak masuk sekolah dasar, ada beberapa alat tes yang bisa dipakai diantaranya adalah Nijmeegse Schoolbekwaamheids Test (NST) dan tes Bender-Gestalt (BG).

Sampai saat ini, khususnya di Indonesia alat tes yang banyak digunakan untuk menggali kesiapan anak masuk sekolah dasar adalah NST. NST tidak hanya digunakan secara praktis pada dunia pendidikan

INSAN Jurnal Psikologi dan Kesehatan Mental

2017, Vol. 2(2), 84-95

doi: 10.20473/jpkm.v2i22017.84-95

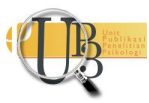


namun juga digunakan sebagai alat untuk mendiagnosa pada penelitian-penelitian yang bertema kesiapan masuk sekolah dasar (Novitawati, 2013). Tes NST disusun oleh F.J. Monks, H. Rost dan N.H. Coffie. NST dikembangkan di Nijmegen - Belanda merupakan pengolahan tes Gopinger dari Jerman (Sulistiyaningsih, 2005). Tes ini banyak digunakan oleh psikolog terutama di bidang pendidikan baik yang bersifat praktis maupun sebagai instrumen penelitian. NST dapat digunakan untuk mengukur aspek-aspek kognitif, motorik halus dan motorik kasar, penilaian sosial, serta emosional. Penyusunan aitem tes NST ini sudah berdasarkan 10 indikator kemampuan yang harus dimiliki oleh anak sebelum masuk ke sekolah dasar. Hal ini menjadikan tes ini cukup populer penggunaannya dalam pengukuran kesiapan anak masuk sekolah dasar.

Sementara itu, tes BG yang dikembangkan oleh Lauretta Bender dan juga sering disebut dengan tes Visual-Motor (Aquarisnawati, dkk., 2011) jarang digunakan untuk mengukur kesiapan masuk sekolah dasar. Tes ini merupakan tes inteligensi non-verbal yang penggunaannya ditujukan untuk mendiagnosis kerusakan otak, meskipun demikian alat tes ini juga dapat digunakan untuk mengetahui kesiapan sekolah, memperkirakan persepsi belajar, mendiagnosis masalah membaca dan belajar, mengevaluasi kesulitan emosional, dan memeriksa retardasi mental (Groth-Manat, 1984 dalam Andayani 2001). Sejauh yang dapat penulis temukan, baru ada satu penelitian yang mengungkap kesiapan masuk sekolah dasar khususnya kemampuan motorik halus yang dianalisis menggunakan tes BG (Aquarisnawati, dkk., 2011).

Penggunaan alat tes psikologi tersebut tidak lepas dari ketepatan alat tes tersebut terhadap tujuan utama suatu pengetesan kesiapan anak masuk sekolah dasar. NST dan BG mempunyai kesamaan fungsi sebagai alat tes kesiapan anak masuk sekolah dasar, namun keduanya memiliki perbedaan dari segi waktu dan kepraktisan dalam penggunaannya. Dari segi waktu penggunaan BG lebih mudah dan lebih cepat dari pada NST. Walaupun antara BG dan NST memiliki fungsi yang sama namun belum ada penelitian yang membuktikan bahwa keduanya mengukur hal yang sama berdasarkan konsep validitas dan reliabilitas alat tes. Menurut Mariyati dan Affandi (2016) bahwa NST telah memiliki validitas dan reliabilitas yang baik ketika diterapkan pada partisipan Jawa Timur (Indonesia), akan tetapi BG belum diketahui properti psikometriknya. NST dipilih sebagai kriteria untuk mengetahui validitas konkuren tes BG dikarenakan adanya bukti bahwa NST memiliki validitas isi dan kontruk yang baik serta memiliki reliabilitas yang tinggi sebagai alat tes untuk mengetahui kesiapan sekolah anak (Mariyati \& Affandi, 2016).

Oleh karena itu, penulis melakukan penelitian terhadap kesiapan anak masuk sekolah dasar ditinjau dari hasil tes NST dan tes BG. Berdasarkan uraian diatas maka tujuan dalam penelitian ini adalah: a) menggambarkan kesiapan sekolah anak ditinjau dari hasil tes NST; b) menggambarkan kesiapan sekolah anak ditinjau dari hasil tes BG; c) menggambarkan hasil perbandingan kesiapan sekolah anak berdasarkan hasil tes antara tes NST dengan tes BG; dan d) menggambarkan hasil validitas konkuren tes BG dengan menggunakan NST sebagai kriteria.

\section{Kesiapan Sekolah Dasar}

Hurlock (1974) menyatakan bahwa kesiapan bersekolah terdiri dari kesiapan fisik dan psikologis. Kesiapan psikologis terdiri dari kesiapan mental, emosi dan sosial. Bentuk kesiapan pada masingmasing aspek adalah sebagai berikut; a) kesiapan fisik meliputi berat dan tinggi badan yang bertambah, visual motorik (koordinasi antara mata dengan tangan) yang berkembang dengan baik; b) kesiapan emosi meliputi kemampuan dalam mengontrol emosi marah, malu, iri dan takut, serta mampu menerima dan melaksanakan tuntutan sekolah serta mampu mandiri/lepas dari bimbingan orang tua maupun orang dewasa lainnya; c) kesiapan sosial meliputi kemampuan dalam menyesuaian diri dengan tuntutan, tugas-tugas dan aturan disekolah, teman, guru dan orang baru; dan d) esiapan

INSAN Jurnal Psikologi dan Kesehatan Mental

2017, Vol. 2(2), 84-95

doi: 10.20473/jpkm.v2i22017.84-95

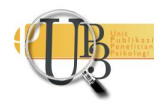


mental meliputi kemampuan berfikir sederhana dan mampu mengenal konsep huruf, angka, bahasa dan gambar, memori.

Adapun Santrock (2002) mengatakan kesiapan sangat berdampingan dengan perkembangan. Perkembangan pada usia tahun-tahun sekolah dasar atau sering disebut masa anak pertengahan menuju akhir masa anak (6/7 hingga 11 tahun), adalah perkembangan motorik kasar lebih halus, koordinasi motorik halus telah berkembang sehingga anak mampu menulis huruf lebih kecil dari sebelumnya, menguasai ketrampilan-ketrampilan fundamental seperti; berhitung, menulis dan membaca, mengalami perkembangan komunikasi/bahasa yang dimiliki, motivasi untuk mendapatkan pengetahuan, perkembangan dengan memori/ingatan khususnya dengan hal-hal yang telah didengar dan dilihatnya. mampu memahami diri, peningkatan harga diri, serta perkembangan emosi.

Sedangkan menurut Comenius, Monks, Rost dan Coffie, (1978 dalam Kustimah, dkk., 2007) minimal tiga kriteria yang harus dimiliki oleh anak yang hendak masuk sekolah dasar atau sederajat adalah; a) menguasai kemampuan-kemampuan panca indra dan pemahaman bahasa yang baik; b) anak harus memiliki motivasi untuk belajar; dan c) anak harus memiliki kematangan dalam bekerja, sehingga dapat menyelesaikan tugas tugas dengan tuntas dan baik.

\section{Nijmeegse Schoolbekwaamheids Test (NST)}

NST awalnya bertujuan untuk mengungkap kemampuan sekolah anak, namun lebih lanjut tes ini juga bertujuan untuk mengetahui tingkat kematangan dan kesiapan anak memasuki pendidikan sekolah dasar. NST juga merupakan salah satu alat yang berfungsi untuk menegakkan prognosis atas prestasi sekolah anak di sekolah dasar, serta untuk mengetahui kematangan kemampuan-kemampuan tertentu anak dan deteksi atas perlunya dilakukannya pelatihan, pembinaan, dan/atau pengembangan. NST dapat mengukur aspek-aspek kognitif, motorik halus dan motorik kasar, penilaian sosial, serta emosional.

NST merupakan tes performasi maksimum, karena dalam sistem penilaiannya menggunakan benar/salah, dimana setiap jawaban benar diberi skor 1 dan setiap jawaban salah diberi skor 0. Pada buku manual tes NST, tes ini terdiri atas 10 sub-tes dalam bentuk gambar dan cerita. Kesepuluh subtes tersebut memiliki tujuan berbeda, diantaranya;

a) Halaman badut dan Jam Weker; kemampuan dalam pengamatan bentuk dan kemampuan membedakan (vorm waarneming en onderscheidings vermogen). Dalam sub-tes ini terdapat 8 soal dengan masing-masing memiliki 2-5 distraktor/pengecoh jawaban dan satu jawaban benar.

b) Halaman buku untuk mengukur kemampuan motorik halus (fijne motoriek). Dalam sub-tes ini terdapat 8 soal dengan menirukan bentuk coretan.

c) Halaman lilin dan jamur untuk mengukur kemampuan pengertian tentang besar, jumlah, dan perbandingan (begrip voor grootte hoeveelheid en verhoudingen). Dalam sub-tes ini, terdapat 8 soal dengan 3-8 distraktor/pengecoh jawaban dan satu jawaban benar.

d) Halaman ikan untuk mengukur pengamatan tajam (scherpwaarnemen). Dalam sub-tes ini terdapat 8 soal dengan menentukan mencari obyek yang tersembunyi pada gambar yang lebih kompleks.

e) Tempat bunga untuk mengukur kemampuan berpikir kritis (kritische waarneming). Dalam sub-tes ini terdapat 8 soal melengkapi gambar yang belum sempurna. 
f) Halaman anak dan kereta boneka untuk mengukur konsentrasi (taakspanning). Dalam subtes ini terdapat 8 soal dengan menunjukkan obyek yang sama pada sekumpulan obyek yang mirip, distraktor/pengecoh lebih kompleks/banyak dibandingkan dari sub tes 1 dan 3.

g) Halaman anak kunci untuk mengukur ingatan (geheugen). Dalam sub-tes ini terdapat 8 soal dengan cara mencari gambar yang sama yang sebelumnya telah dilihat/dicoba, memiliki 8 distraktor/pengecoh dan 8 jawaban benar.

h) Halaman anggur dan sepeda digunakan untuk mengukur pengertian objek dan penilaian situasi (object begripen situatieboordeling). Dalam sub-tes ini terdapat 8 soal dengan masingmasing memiliki 2-3 distraktor/pengecoh jawaban dan satu jawaban benar.

i) Halaman televisi berupa perintah menirukan cerita (weergeven van een verhaaltje). Dalam sub-tes ini terdapat 8 soal dengan cara mencari gambar yang sama dengan isi dari cerita yang telah dibacakan sebelumnya, memiliki 8 distraktor/pengecoh dan 8 jawaban.

j) Halaman kupu-kupu berupa perintah menggambar orang (menstekening). Penilaian dimulai dengan 1-8 sesuai dengan kunci jawaban sesuai dengan kelengkapan dalam gambar.

\section{Tes Bender-Gestalt (BG)}

Bender Visual Motor Gestalt Test yang dikenal dengan Tes Bender-Gestalt (BG) adalah salah satu tes yang digunakan untuk mengetahui kesiapan sekolah anak. Tes BG dikembangkan oleh Lauretta Bender dan juga sering disebut dengan tes Visual-Motor (Gregory, 2011). Tes ini terdiri dari 9 gambar dengan ukuran media/kertas $4 \times 6$ inchi yang secara berurutan disajikan pada partisipan dengan instruksi partisipan harus menggambarnya pada lembar kertas HVS kosong ukuran A4 (8.5×11 inchi), kemudian gambar partisipan tersebut dinilai derajat ketepatan relatif dan integrasi keseluruhan (Andayani, 2001). Kesembilan gambar dalam tes BG ini diadaptasi dari gambar-gambar Wertheimer (Pratikto, 2003 dalam Aquarisnawati, dkk., 2011) yang digunakan untuk eksperimen perseptual.

Ada ahli yang menggolongkan tes BG sebagai tes persepsi visual, selain itu ada juga yang menganggap sebagai tes koordinasi motorik, sedangkan Koppitz (1975 dalam Gregory, 2011) mengatakan bahwa tes BG sebagai tes Integrasi Visual-Motor (Andayani, 2001). Menurut Monks, Rost, dan Coffie (dalam Sulistiyaningsih, 2005), tes BG merupakan tes inteligensi non-verbal yang digunakan untuk mendiagnosis kerusakan otak. Meskipun demikian tes BG ini juga digunakan untuk hal lainnya, seperti; untuk mengetahui kesiapan sekolah, memperkirakan prestasi belajar, mendiagnosis masalah membaca dan belajar, mengevaluasi kesulitan emosional, serta memeriksa retardasi mental.

Sementara itu menurut (Groth-Marnat, 2010) fungsi utama tes BG adalah mendeteksi perubahan terkait perkembangan dalam proses koordinasi visual-motorik dalam rentang 4-15 tahun dan setelah usia 70 tahun dengan atau tanpa kerusakan otak. Selain itu, tes BG juga dapat dipakai sebagai tes perkembangan untuk anak usia 4 tahun sampai dengan 10 tahun (Groth-Marnat, 2010). Brannigan \& Decker (2003, dalam Groth-Marnat, 2010) mengatakan bahwa dalam prosesnya tes BG dapat digunakan untuk tes memori atau recall.

Ada banyak metode penilaian tes BG, diantaranya Pascal-Suttell method, Hain Scoring method, Koppitz Developmental Bender Test Scoring System, metode skoring L. Benner, metode skoring H. Santicci (Hendratno, 2015). Metode scoring BG tes yang cukup populer adalah pendekatan Koppitz yang

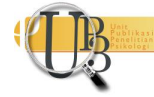


menggunakan Sistem Manual Skoring Perkembangan pada anak-anak, lengkap dengan contoh-contoh kasus (Koppitz, 1975 dalam Gregory, 2011). Penilaian tes BG dengan menggunakan metode $\mathrm{H}$. Santucci (Hendratno, 2015) memiliki metode skoring yang lebih teruji dan sederhana dengan hanya melakukan skoring pada 5 gambar yang dinilai cukup merepresentasikan seluruh 9 gambar yang disajikan, yaitu gambar A, 2, 3, 4, dan 7. Kelima gambar tersebut memiliki kesamaan, yaitu sudut, orientasi, posisi relatif dan tambahan.

\section{E T O D E}

\section{Desain Penelitian}

Penelitian ini bertujuan untuk mengetahui validitas tes BG dengan menggunakan NST sebagai kriteria. Oleh karena itu, desain penelitian yang dipilih oleh penulis adalah penelitian kuantitatif dengan pendekatan survei korelasional.

\section{Partisipan Penelitian}

Partisipan dalam penelitian ini adalah siswa sekolah dasar yang telah mengikuti tes NST dan tes BG dalam tes persiapan sekolah dengan jumlah partisipan 400 anak dengan sebaran sekolah dasar dijawa timur, diantaranya: Probolinggo, Sidoarjo dan Bangkalan. Namun dari 400 hasil tes yang layak dilanjutkan dalam analisis hanya 397 anak. Pengambilan data dalam penelitian ini telah disetujui oleh pihak masing-masing pihak sekolah yang menjadi tempat penelitian. Aadapun sebaran siswa sekolah dasar yang manjadi subjek penelitian sebagaimana pada tabel 1 dibawah ini;

Tabel 1. Partisipan Penelitian (N=397)

\begin{tabular}{cc}
\hline Kota/Kabupaten & Jumlah \\
\hline Probolinggo & 162 anak \\
Sidoarjo & 169 anak \\
Bangkalan & 65 anak \\
\hline
\end{tabular}

\section{Pengukuran}

Variabel dalam penelitian ini adalah variabel kesiapan masuk sekolah dasar, sedangkan Data dalam penelitian ini menggunakan dua instrumen, yaitu NST dan tes BG.

Nijmeedgse School Bekwaamheids Tes (NST). NST “tes Boekje Vorm A" merupakan salah satu alat tes yang berfungsi mengukur kesiapan masuk sekolah dasar yang dipopulerkan oleh Monks, Rost, dan Coffie (Supartini, 2006). Sulistiyaningsih (2005) menyebutkan NST bersifat non-verbal yang yang bertujuan untuk mengukur aspek-aspek kognitif, penilaian sosial, motorik halus dan kasar, serta emosional anak. NST terdiri dari 10 sub tes yang telah diuji reliabelitasnya dari sample penelitian sebanyak 343 siswa diusia 6-7 tahun didapat koefisien reliabilitas rxx=0.851, artinya alat tes dapat diterima/digunakan untuk mengukur kesiapan masuk sekolah (Mariyati dan Afandi, 2016).

Bender Visual Motor Gestalt Test. Bender Visual Motor Gestalt Test yang dikenal dengan Tes BG adalah salah satu tes yang digunakan untuk mengetahui kesiapan sekolah anak. Tes BG dikembangkan oleh Lauretta Bender dan juga sering disebut dengan tes Visual-Motor (Gregory, 2011). Tes ini terdiri dari 9 gambar dengan ukuran media/kertas $4 \times 6$ inchi yang secara berurutan disajikan pada partisipan dengan instruksi partisipan harus menggambarnya pada lembar kertas HVS kosong ukuran A4 (8,5 x 11 inchi), kemudian gambar partisipan tersebut dinilai derajat ketepatan relatif dan integrasi

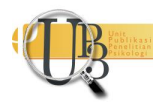


keseluruhan (Andayani, 2001). Metode skoring yang digunakan dengan dengan pendekatan $\mathrm{H}$. Santucci:
a. Figur A skoring aitemnya terdiri dari 4 aspek dengan skor tertinggi 10
b. Figur 2 skoring aitemnya terdiri dari 3 aspek dengan skor tertinggi 7
c. Figur 3 skoring aitemnya terdiri dari 4 aspek dengan skor tertinggi 11
d. Figur 4 skoring aitemnya terdiri dari 4 aspek dengan skor tertinggi 11
e. Figur 7 skoring aitemnya terdiri dari 4 aspek dengan skor tertinggi 10

\section{Analisis Data}

Teknik analisis data yang digunakan dalam penelitian ini adalah analisis statistik deskriptif serta korelasi Pearson's $r$ yang dihitung dengan bantuan program software Microsoft Excel dan SPSS 17 for Windows.

\section{H A S I L P E N ELIT I A N}

\section{Kesiapan Sekolah Anak Ditinjau dari Hasil NST}

Kategorisasi skor kesiapan sekolah dasar anak ditinjau dari hasil tes NST yang didasarkan pada perhitungan standar deviasi (48.86) dan rerata empirik (8.98) dari data partisipan penelitian, sehingga menghasilkan tabel kategorisasi Tes NST:

Tabel 2. Dasar Kategorisasi NST

\begin{tabular}{lrrr}
\hline \multicolumn{1}{c}{ Kategori } & \multicolumn{2}{c}{ Rentang Skor NST } \\
\hline Sangat Siap & & $\mathrm{X} \geq$ & 57.84042 \\
Siap & 39.87747 & $\leq \mathrm{X}<$ & 57.84042 \\
Belum siap & & $\mathrm{X}<$ & 39.87747 \\
\hline
\end{tabular}

Apabila skor partisipan diatas atau sama dengan 57.84042 maka partisipan tergolong sangat siap. Jika skor partisipan lebih dari atau sama dengan 39.87747, sampai dengan dibawah 57.84042 tergolong siap, sedangkan jika skor partisipan dibawah 39.87747 tergolong belum siap. Berikut adalah hasil analisis deskriptif kesiapan sekolah dasar berdasarkan skor NST berupa diagram lingkaran.

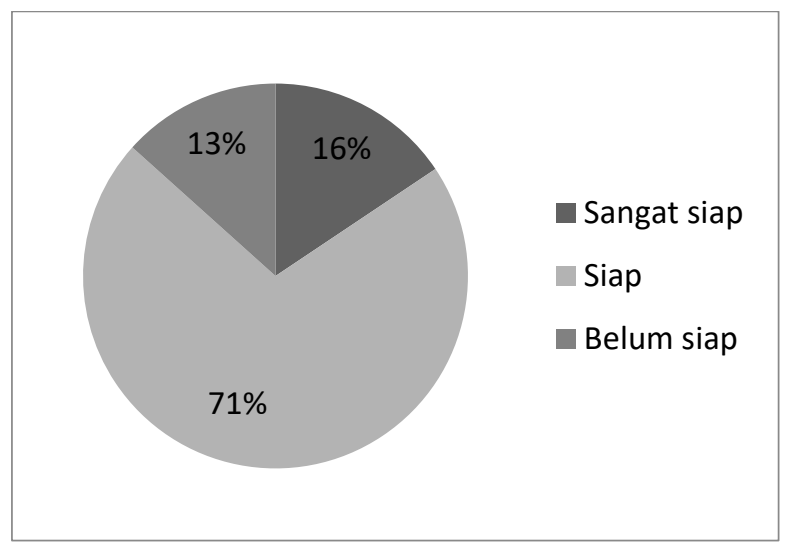

Diagram 1. Sebaran Skor Kesiapan Masuk Sekolah Dasar Berdasarkan Skor NST 
Diagram tersebut menggambarkan bahwa persentase paling dominan hasil tes NST siswa telah siap untuk mengikuti sekolah dasar yang terbukti skor dominan adalah skor yang menunjukkan kesiapan yaitu sebanyak 71\% siswa. Adapun siswa yang sangat siap untuk mengikuti pendidikan sekolah dasar hasil analisis tes NST sebanyak 16\% dan yang menunjukkan ketidaksiapan siswa untuk mengikuti sekolah dasar sebanyak 13\% dari jumlah total siswa yang mengikuti tes NST.

\section{Kesiapan Sekolah Anak Ditinjau dari Hasil Tes BG}

Kategorisasi skor kesiapan sekolah dasar anak ditinjau dari hasil tes BG yang didasarkan pada perhitungan standar deviasi (22.45) dan rerata empirik (8.47) dari data partisipan penelitian, sehingga menghasilkan tabel kategorisasi Tes BG:

Tabel 2. Dasar Kategorisasi Skor BG

\begin{tabular}{lrrr}
\hline Kategori & \multicolumn{3}{c}{ Rentang Skor BG } \\
\hline Tinggi & & $X \geq$ & 30.91908 \\
Sedang & 13.97765 & $\leq X<$ & 30.91908 \\
Rendah & & $X<$ & 13.97765 \\
\hline
\end{tabular}

Apabila skor partisipan diatas atau sama dengan 30.91908 maka partisipan tergolong sangat siap. Jika skor partisipan lebih dari atau sama dengan 13.97765, sampai dengan dibawah 30.91908 tergolong siap, sedangkan jika skor partisipan dibawah 13.97765 tergolong belum siap. Berikut adalah hasil analisis deskriptif kesiapan sekolah dasar berdasarkan skor NST berupa diagram lingkaran.

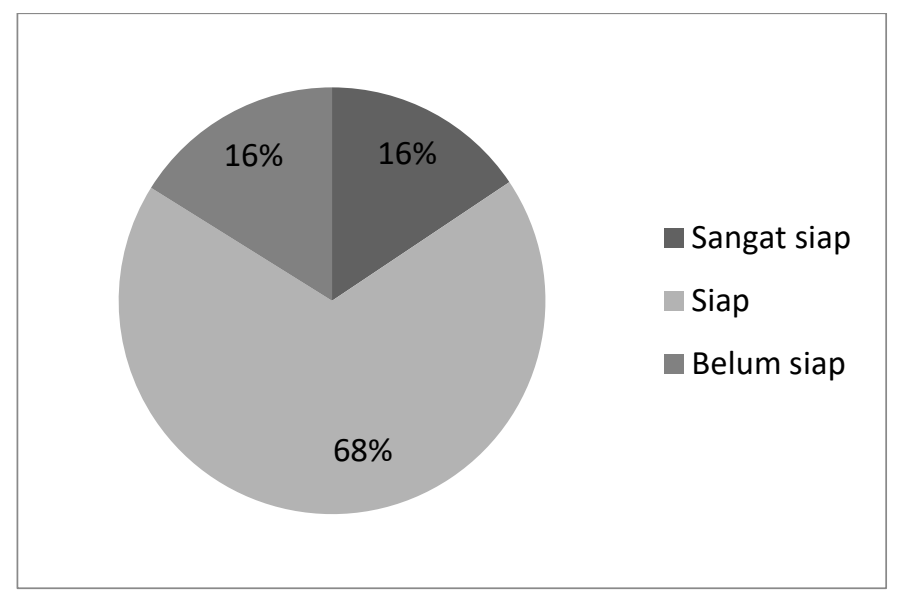

Diagram 2. Sebaran Skor Kesiapan Masuk Sekolah Dasar Berdasarkan Skor BG

Hasil analisis dari tes BG yang diberikan kepada siswa sekolah dasar awal menunjukkan bahwa sebagian besar siswa telah siap mengikuti pendidikan sekolah dasar yaitu sebanyak $68 \%$ siswa, bahkan dari total keseluruhan siswa ternyata ditemukan ada $16 \%$ siswa sangat siap mengikuti sekolah dasar. Namun dari sekian banyak siswa yang telah mengikuti tes BG ternyata ada juga siswa yang belum siap atau perlu pendampingan khusus agar mereka dapat mengikuti kegiatan belajar di sekolah dasar yaitu sebanyak 16\% siswa. 
Perbandingan Kesiapan Sekolah Anak Berdasarkan Hasil Tes NST dengan Tes BG.

Tabel 3. Perbandingan sebaran skor partisipan pada NST dan Tes BG (N=397)

\begin{tabular}{cccccc}
\hline & NST & & \multicolumn{3}{c}{ Tes BG } \\
\hline Kategorisasi & Total & $\begin{array}{c}\text { Persentase } \\
\text { sebaran skor }\end{array}$ & Kategorisasi & Total & $\begin{array}{c}\text { Persentase } \\
\text { sebaran skor }\end{array}$ \\
\hline Sangat siap & 62 & $16 \%$ & Sangat siap & 62 & $16 \%$ \\
Siap & 282 & $71 \%$ & Siap & 271 & $68 \%$ \\
Belum siap & 53 & $13 \%$ & Belum siap & 64 & $16 \%$ \\
\hline
\end{tabular}

Perbandingan tes kesiapan sekolah anak hasil analisis antara NST dan tes BG menunjukkan pola yang sama yaitu persentase terbanyak berada pada posisi siswa telah siap mengikuti sekolah dasar denga persentase hasil tes NST sebesar 71\% sedangkan hasil tes BG sebesar 68\%. Sedangkan siswa yang sangat siap juga nampak pada kedua hasil NST dan BG Test sama-sama menunjukkan persentase yang sepadan yaitu sebesar 16\%. Adapun siswa yang belum siap pada kedua tes menunjukkan sedikit perbedaan, untuk NST sebesar 13\% sedangkan tes BG sebesar 16\% dari keseluruhan siswa yang mengikuti tes.

Hasil analisis menunjukkan bahwa persentase paling dominan hasil NST siswa telah siap untuk mengikuti sekolah dasar yang didukung data bahwa proporsi yang dominan adalah partisipan yang menunjukkan kesiapan, yaitu sebanyak 71\% siswa. Adapun siswa yang sangat siap untuk mengikuti pendidikan sekolah dasar, berdasarkan hasil NST sebanyak 16\%. Adapun hasil tes BG yang mendeteksi kematangan siswa sekolah dasar awal, menunjukkan bahwa sebagian besar siswa telah siap mengikuti pendidikan sekolah dasar yaitu sebanyak 68\% siswa. Bahkan dari total keseluruhan siswa ternyata ditemukan ada $16 \%$ siswa sangat siap mengikuti sekolah dasar.

Hasil dari analisis data secara deskriptif dari kedua alat tes tersebut, yaitu NST dan tes BG mengenai kesiapan sekolah siswa sekolah dasar awal menunjukkan pola kecenderungan yang sama. Pola yang sama tersebut ditampakkan dari persentase terbanyak berada pada posisi siswa telah siap mengikuti sekolah dasar dengan, proporsi partisipan yang siap berdasarkan hasil NST sebesar 71\%, sedangkan hasil tes BG sebesar 68\%. Siswa yang sangat siap juga nampak pada hasil NST dan tes BG yang samasama menunjukkan persentase yang sepadan yaitu sebesar $16 \%$.

\section{Validitas Konkuren Tes BG dengan NST sebagai Alat Tes Kriteria}

Hasil analisis korelasi antara skor tes BG dengan skor NST (sebagai kriteria) menunjukkan korelasi yang sedang dan positif ( $r=.337$, nilai $\mathrm{p}<.01$ ). Adanya hubungan yang positif tersebut menjelaskan bahwa tes BG memiliki validitas konkuren bila dibandingkan dengan alat yang menjadi kriterianya, yaitu NST.

\section{I S K U S I}

Adanya pola kesamaan dari kedua tes tersebut karena secara teori antara NST dan tes BG memiliki kemiripan dalam hal konten yang digali yaitu kesiapan sekolah anak usia dasar awal (Monks, Rost \& Coffie dalam Sulistiyaningsih, 2005) meskipun soal-soal yang disajikan antara keduanya berbeda. Kesamaan antara NST dan tes BG salah satunya keduanya menunjukkan tes kematangan pengamatan (visual), artinya dalam kematangan pengamatan dalam tes BG nampak pada kemampuan melihat

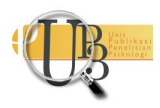


bentuk (lingkaran, garis dan sudut), posisi dan/atau arah (atas-bawah, kiri-kanan, atau diagonal) serta perpotongan antara dua garis atau lebih yang merupakan bagian dari tes integrasi visual-motor (Andayani, 2001; Koppitz, 1975 dalam Gregory, 2011; Aquarisnawati, 2011). Sedangkan kematangan visual pada NST ditunjukkan pada kemampuan membedakan dan kesamaan bentuk, mencari obyek tertentu dalam satuan gambar, menunjukkan gambar tertentu sesuai dengan instruksi (Monks, Rost, dan Coffie dalam Sulistiyaningsih, 2005).

Selanjutnya, kedua alat tes tersebut menunjukkan tes kematangan motorik halus (kualitas coretan yang dihasilkan dari otot jari tangan) (Andayani, 2001; Koppitz, 1975 dalam Gregory, 2011; Aquarisnawati, 2011), artinya dalam kematangan motorik halus dalam tes BG nampak pada kemampuan hasil coretan gambar sesuai dengan contoh baik bentuk, orientasi maupun perpotongan dua garis atau bentuk atau bangun sedangkan kan pada tes NST hanya melihat kemampuan hasil coretan gambar sesuai dengan contoh yang tidak sekompleks tes BG.

Kesamaan berikutnya antara keduanya mengungkap kemampuan kognitif (Monks, Rost, dan Coffie dalam Sulistiyaningsih, 2005). Aspek kognitif dari NST dapat diketahui dari skor-skor pada sub-tes yang berkaitan dengan konsep matematis, memori, pemahaman cerita, pengamatan kritis, konsentrasi serta pemahaman membedakan objek. Sementara itu, aspek kognitif dari tes BG dapat diketahui dari kemampuan menggambar sesuai stimulus figur yang diberikan baik dari segi proporsi gambar, integrasi gambar, distorsi gambar serta rotasi gambar. Selain itu, kedua alat tes membutuhkan kematangan terhadap perhatian dan konsentrasi. Seta sama-sama memiliki kemampuan dalam mengungkap aspek emosi. Pengukuran aspek emosi pada NST dapat diketahui dari sub-tes gambar orang pada halaman kupu-kupu, dimana pada sub-tes ini diminta untuk menggambar orang lengkap. Semakin lengkap dan jelas gambar orang yang digabar mengindikasikan matangnya emosi dan sosial anak. Sementara itu, untuk mengetahui aspek emosi dari tes BG dapat dilihat dari coretan gambar (kuat-lemahnya coretan), letak gambar, serta dari besar kecilnya proporsi gambar.

Namun demikian antara antara NST dan tes BG memiliki perbedaan secara umum nampak pada kompleksitas yang diungkap. Aspek yang diukur dalam NST lebih banyak dibandingkan tes BG. Tes NST umumnya meliputi pengukuran terhadap memori, konsep jumlah dan perbandingan, pengetahuan umum yang bertujuan untuk melihat minat individu terhadap lingkungan dalam proses belajar, pemahaman terhadap konsep bahasa (Monks, Rost, dan Coffie dalam Sulistiyaningsih, 2005). Sedangkan tes BG megungkap visual-motorik (Koppitz, 1975 dalam Gregory, 2011; Andayani, 2001), namun juga dapat mengungkap kemampuan daya bayang ruang dan perencanaan serta mendeteksi kerusakan otak individu. Dalam hal penggunaan alat tes, administrasi serta skoring untuk NST lebih rumit serta membutuhkan waktu lebih lama dari pada tes BG. Artinya tes BG cara administrasi tes yang relatif sederhana jika dibandingkan dengan NST yang sama-sama mengungkap kesiapan masuk sekolah anak usia dasar awal.

Adanya kesamaan hasil analisis secara deskriptif dan konten yang digali berdasarkan teori antara NST dan tes BG ternyata juga dibuktikan dari hasil analisis psikometri. Dalam hal ini analisis psikometri digunakan untuk mengentahui validitas konkuren alat tes BG dengan NST sebagai kriterianya, dimana hasil korelasi antara skor tes BG dengan skor NST (sebagai kriteria) menunjukkan korelasi sedang dan positif. Dengan demikian, tes BG memiliki validitas konkuren yang baik apabila dibandingkan dengan alat yang menjadi kriterianya yaitu NST.

Menurut Sudjana (1991) validitas konkuren merupakan hasil tes yang memiliki kesamaan dengan tes yang sejenis, dalam hal ini alat tes yang sejenis dengan tes BG adalah NST sebagaimana hasil analisis deskriptif dan teoritik yaitu sama-sama mengungkap kesiapan siswa sekolah dasar awal (Monks, Rost, dan Coffie dalam Sulistiyaningsih, 2005). Dikatakan suatu instrumen tes memiliki validitas konkuren apabila hasil dari tes tersebut sesuai dengan kriteria tes yang sudah ada (Widoyoko, 2009) dan antara

INSAN Jurnal Psikologi dan Kesehatan Mental

2017, Vol. 2(2), 84-95

doi: 10.20473/jpkm.v2i22017.84-95 
hasil skor alat tes yang dicari validitasnya (tes BG) memiliki hubungan dengan alat tes kriterianya (Sukardi, 2011) yaitu NST melalui indeks korelasi berdasarkan perhitungan korelasi.

\section{S I M P U L A N}

Dengan hasil ukur dan analisis secara deskriptif antara NST dan tes BG pada partisipan yang sama dan waktu yang sama menunjukkan bahwa keduanya memiliki pola yang sama dalam mengukur kesiapan sekolah pada anak usia sekolah dasar awal. Selain itu, tes BG memiliki validitas konkuren yang cukup baik berdasarkan kriterianya, yaitu NST.

Implikasi penelitian ini bagi siswa yang belum siap untuk mengikuti sekolah dasar awal berdasarkan hasil tes NST dan tes BG sebaiknya guru memberikan bimbingan atau perhatian yang lebih besar dari pada siswa yang sudah siap mengikuti sekolah dasar, sedangkan bagi wali murid hendaknya memberikan bimbingan kepada anaknya yang belum siap saat belajar dirumah. Bagi praktisi yang bergerak dibidang perkembangan anak maupun pendidikan, alat tes BG dapat digunakan untuk mengukur kesiapan sekolah untuk anak usia sekolah dasar awal selain menggunakan NST. Dari segi administrasi, tes BG lebih praktis dan memiliki validitas yang baik berdasarkan hasil analisis data. Bagi peneliti selanjutnya, ada peluang properti psikometrik tes BG dapat ditelaah lebih lanjut dengan menggunakan Item Respon Theory agar hasil yang diperoleh lebih komperhensif.

\section{U C A P A N T E R I MAKASIH}

Penulis mengucapkan terimakasih kepada Direktorat Riset dan Pengabdian Masyarakat Direktorat Jenderal Penguatan Riset dan Pengembangan Kementerian Riset, Teknologi, dan Pendidikan Tinggi yang telah mensponsori penelitian ini.

\section{PUSTAKA ACUAN}

Andayani, B. (2001). Kemampuan Psikologis Anak Dengan Tulisan Tangan Buruk. Jurnal Psikologi, 28(2), 77-96.

Anastasi, A. \& Urbina, S. (2006). Tes Psikologi. Jakarta: Penerbit Indeks.

Aquarisnawati, P., Mustami'ah, D., \& Riskasari, W. (2012). Motorik Halus pada anak usia prasekolah ditinjau dari bender gestalt. Jurnal Insan Media Psikologi, 13(3).

Gregory, R.J. (2011). Tes Psikologi: Sejarah, Prinsip, dan Aplikasi Jilid 2, Edisi 6 (Terj). Jakarta: Penerbit Erlangga.

Groth-Marnat, G. (2010). Hanbook of Psychological Assessment - Edisi 5. (Terj. Helly P.S \& Sri Mulyantini S). Yogyakarta: Pustaka Pelajar.

Hendratno, L. (2015). Bender Gestalt dan Bourdon Test. Surabaya: Naira Institut of Human Development

Hurlock, E.B. (1974). Personality Development. New Delhi: Tata McGraw-Hill, Inc.

Kustimah, Abidin, \& Kusumawati (2007). Gambaran Kesiapan Anak Masuk Sekolah Dasar Ditinjau dari Hasil Test N.S.T (Nijmeegse Schoolbekwaamheids Test). Fakultas Psikologi-Universitas Padjadjaran. http://pustaka.unpad.ac.id/wp-content/uploads/2009/08/asesmen klinis.pdf. (9 Oktober 2014) 
Mariyati, L. I., \& Affandi, G. R. (2016). Tepatkah Nijmeegse Schoolbekwaamheids Test (NST) untuk Mengukur Kesiapan Sekolah Siswa Sekolah Dasar Awal pada Konteks Indonesia? (Analisis Empirik Berdasar Teori Tes Klasik). Jurnal Ilmiah Psikologi Terapan, 4(2), 194-211.

Novitawati, N. (2013). Kesiapan Sekolah Anak Taman Kanak Kanak Berbasis Model Pembelajaran Sentra. Jurnal Pendidikan Usia Dini, 7(1), 109-132.

Papalia, D.E., Old, S.W., Feldman, R.D. (2008). Human Development. (Terj. A.K. Anwar). Edisi kesembilan. Jakarta: Kencana Prenada Media Group.

Santrock, J. (2002). Life-span Development (perkembangan masa hidup). (Terj. A. Chusairi \& Damanik). Jakarta: Penerbit Erlangga

Sulistiyaningsih, W. (2005). Kesiapan bersekolah ditinjau dari jenis pendidikan prasekolah anak dan tingkat pendidikan orang tua. Jurnal Psikologia, 1(1).

Sudjana, N. (1991). Penilaian Hasil Proses Belajar Mengajar. Rosdakarya: Bandung.

Sukardi, H.M. (2011). Evaluasi Pendidikan: Prinsip dan Operasionalnya. Jakarta: Bumi Aksara.

Supartini, E. (2006). Pengukuran Kesiapan Sekolah. JPK: JURNAL PENDIDIKAN KHUSUS, 2(2), 61-71.

Widoyoko, E.P. (2009). Evaluasi Program Pembelajaran: Panduan Praktis Bagi Pendidik dan Calon Pendidik. Yogyakarta: Pustaka Pelajar. 